Article

\title{
Future Policy and Technological Advancement Recommendations for Enhanced Adoption of Electric Vehicles in South Africa: A Survey and Review
}

\author{
Mokhele Edmond Moeletsi 1,2,3 (D) \\ 1 Agricultural Research Council—Natural Resources and Engineering, Private Bag X79, \\ Pretoria 0001, South Africa; moeletsim@arc.agric.za or mmoeletsi@hotmail.com; Tel.: +27-12-310-2537; \\ Fax: +27-12-323-1157 \\ 2 Business School, Nelson Mandela University, 2nd Avenue Campus, Summerstrand, \\ Port Elizabeth 6001, South Africa \\ 3 Risk and Vulnerability Science Centre, University of Limpopo, Private Bag X1106, Sovenga, \\ Polokwane 0727, South Africa
}

check for updates

Citation: Moeletsi, M.E. Future Policy and Technological Advancement Recommendations for Enhanced Adoption of Electric Vehicles in South Africa: A Survey and Review. Sustainability 2021, 13, 12535. https://doi.org/10.3390/ su132212535

Academic Editors: Tommi Inkinen, Tan Yigitcanlar and Mark Wilson

Received: 10 August 2021

Accepted: 27 September 2021

Published: 13 November 2021

Publisher's Note: MDPI stays neutral with regard to jurisdictional claims in published maps and institutional affiliations.

Copyright: (C) 2021 by the author. Licensee MDPI, Basel, Switzerland. This article is an open access article distributed under the terms and conditions of the Creative Commons Attribution (CC BY) license (https:/ / creativecommons.org/licenses/by/ $4.0 /)$.

\begin{abstract}
There are major concerns globally on the increasing population of internal combustion engine (ICE) vehicles and their environmental impact. The initiatives for the advancement of alternative propulsion systems, such as electric motors, have great opportunities, but are marked by a number of challenges that require major changes in policies and serious investment on the technologies in order to make them viable alternative mobility sources around the world. South Africa has struggled a lot in adopting electric vehicles among all the emerging countries. This is mostly attributed to a non-conducive environment for electric vehicle adoption. This study administered a survey consisting of Likert-scale questions in the Gauteng Province to gather information on people's views on some of the major concerns around electric vehicle technology. The survey results demonstrated that Gauteng residents perceive electric vehicle price as the main constraint towards adoption of the technology and introduction of government policy towards addressing this challenge would be helpful. Some of the suggested interventions, such as the rollout of purchasing subsidies and tax rebates, received a high level of satisfaction among the respondents. Future initiatives that tackle issues of charging infrastructure network also received high satisfaction. Thus, there is a need for all stakeholders in the South African automotive industry to improve the enabling environment for the adoption of electric vehicles.
\end{abstract}

Keywords: electric vehicle policy; electric vehicle incentives; charging infrastructure; green transport strategy; Gauteng province

\section{Introduction}

Ownership of vehicles is growing at a faster rate than the human population. The world had 50 million cars in 1950 and the figure rose to 600 million after 50 years; this is expected to increase to 3 billion vehicles by 2050 [1,2]. Without downplaying the importance of vehicles in our lives, their ever increasing population has a negative impact on the environment through increased pollution and emission of greenhouse gases resulting from the combustion of fossil fuels [2]. This has resulted in emissions from the transport sector alone being at around $25 \%$ of the total global emissions [3]. In South Africa, transport contributes close to $11 \%$ of total emissions with road transport's share being around $91 \%$ [4]. It is evident that carbon emissions from the transport sector must be prioritised if the global community is serious about reducing greenhouse gas emissions [5]. At a country level, shifting towards electric vehicles will enable South Africa to attain its national development goals as well as the sustainable development goal (SDG) targets, which include transitioning to a low-carbon economy and providing a sustainable transport system [6]. 
Substituting internal combustion engine (ICE) vehicles with electric vehicles (EVs) can be a solution for offering urban dwellers a better quality of life with less pollution [7]. The use of EVs has a huge potential of reducing greenhouse gas emissions in the transport sector $[7,8]$. Thus, it is important for governments around the world to initiate policy measures that support the market penetration of EVs both at district and national level [5]. Electric cars have other advantages as compared to conventional cars, including high energy efficiency, reduced noise and low operating costs [9]. Nevertheless, these socioeconomic benefits are accompanied by multiple challenges, such as high purchase prices, low driving range in between recharging, low variety of models, small loading capacity, a need for regular charging, low maximum speed and low acceleration [2,10]. Policy makers should seek ways to understand these challenges and propose strategies that ensure the advancement of the technology while taking into consideration local factors [11].

In South Africa, the adoption of electric vehicles has been extremely slow with less than 1000 battery EVs and plug-in EVs sold since their introduction on the market in $2013[12,13]$. Sales figures of new EVs in 2020 were less than 100, with the best year so far being 2015, when around 120 EVs were sold [14,15]. Preliminary studies in South Africa on consumer perceptions of electric vehicle purchases demonstrated a number of socioeconomic and technological barriers that impede the diffusion of EVs in the automotive market [16,17]. The data from the sales figures do not show an increase in the vehicles as in other emerging countries, such as China and India, implying that there is a non-conducive environment for the adoption of EVs in South Africa [12,18-21]. In India alone, close to a million EVs were sold in 2017 [22]. Is this a matter of technology introduced; supporting infrastructure; prices of the vehicles or the type of vehicles? According to Dane [23], South Africa does not have any major policy that can assist the country in shaping the way forward regarding the electric vehicle market and proportion of local industry. It remains to be seen whether the newly adopted green transport strategy will provide the stimulus needed to attract the investment into electric mobility exceeding US\$513 billion by 2050 on electric vehicles and US $\$ 488$ billion by 2030 on hybrid vehicles stated in South Africa's intended contributions to climate change response [4,24].

This study assesses some of the policy recommendations and technological advances that might act as a stimulus to future electric vehicle adoption in South Africa. The research question is as follows: What are the possible impetuses that can be explored to improve the diffusion of electric vehicles in the South African automotive market? The article seeks to augment studies that are already available from other regions in the world with consumer perceptions on EVs from the African continent.

\section{Materials and Methods}

To assess the policy recommendations that will entice consumers to purchase electric vehicles in the future, a web-based survey was conducted on Survey Monkey from 28 September to 8 November 2018. The study employed a convenience sampling approach in which questionnaires were distributed at first to all the colleagues of the author's workplace, friends, family members and people working in municipalities, universities and other major companies in the Gauteng Province. The initial contacts were encouraged to pass the questionnaire to their network of people. The weblink (https:/ / www.surveymonkey.com/ r/electriccars [last accessed on 12 December 2018]) was distributed to the respondents via email, Facebook, short messaging system (SMS) and WhatsApp [16,25]. The study targeted people residing in the Gauteng Province with the potential to purchase a vehicle in the future.

The survey was composed of two parts: general questions and recommendations for policy and improvement questions. In total, 25 of the 26 questions were close-ended multiple choice, which enabled quantitative analysis of the information. Almost all the questions were of a Likert-scale type, mostly asking the degree to which the respondent agrees or disagrees with a certain statement. All these multiple-choice questions were compulsory for all the respondents. The core questions concentrated on both the technological and 
policy recommendations that were geared towards high consumer acceptance of electric mobility. The two sections present in the questionnaire were as follows [26,27]:

1. General information: Age, gender, race, education, monthly disposable income, region of residence, type of dwelling, property ownership, number of cars owned, type of car owned, type of fuel of the car, engine size of the car, kilometres travelled on a daily basis, awareness that cars emit greenhouse gases that cause climate change, awareness of any full electric vehicle in the South African market and awareness of anybody owning an electric car.

2. Recommendations on policy and adjustments: Chances of buying a full electric vehicle if driving range is increased drastically, chances of buying a full electric vehicle if there will be a charging station at workplace, chances of buying a full electric vehicle if there will be charging station at each of the major fuel filling stations, chances of buying a full electric vehicle if vehicle variety in South African industry is increased, chances of buying a full electric vehicle if there will be government financial incentives in the form of tax rebates, savings in annual car license renewal and toll gate exemptions, chances of buying an electric car if the government mandates a dedicated lane for EVs in major congested roads and any other suggestions that would make them buy an electric vehicle.

To check for the reliability or internal consistency of the questionnaire used to investigate the policy recommendations for South Africa for the adoption of electric vehicles, Cronbach's alpha statistic was used. Cronbach's alpha tests whether the Likert-scale type of multiple-choice questions are reliable $[28,29]$. The equation used is as follows:

$$
\propto=\frac{N * \bar{c}}{\bar{v}+(N-1) * \bar{c}}
$$

where $N$ is the number of items, $\bar{c}$ is the average covariance between item-pairs and $\bar{v}$ is the average variance.

The results of the Cronbach's alpha showed a value of 0.899 , which is above 0.8 , indicating that the survey questions for the future recommendation of policy relating to electric vehicle adoption in South Africa show high level of reliability [29].

The responses to the closed-ended survey questions were converted to percentages based on the total number of responses for that particular question that relates to a certain perceived recommendation for policy adjustments in an effort to improve the adoption of EVs in South Africa. The frequency table generated was used as a basis for analysis of the responses from the consumers. The XLSAT statistical software was also used to test whether there were significant differences in the responses against the demographical factors using the chi-square test at $95 \%$ and $90 \%$ confidence level. The recommendations on the role that government policies can play towards increasing the market share of electric vehicles based on the results of the survey was also deliberated.

\section{Results and Discussion}

\subsection{Basic Information}

In total, 402 complete responses were obtained from the survey administered from 24 September to 8 November 2018. All the data were used in the analysis. The respondents were mostly aged between 25 and 44 , with over $70 \%$ of the total survey population. Less than $2 \%$ of the respondents were aged below 18 years and over 65 years. There was a close to 50-50 gender representation, with most people being of African descent (89\%). Most of the respondents were highly literate (over $80 \%$ post-matric qualification) in contrast to the results of the 2011 census, which stated that over $80 \%$ of people living in Gauteng had a matric qualification or lower. This is an indication of the biasness in the sample obtained in the study. Over $50 \%$ of the people were living in the Tshwane metropolitan area (Pretoria). In terms of car ownership, the majority of the people had one car (45\%), with $26 \%$ having no car and $21 \%$ having two cars, while less than $10 \%$ owned more than two cars. Over $90 \%$ 
of the respondents were aware of the negative impacts that fumes from ICE vehicles have on the environment.

\subsection{Recommendations on Policy and Advancements of Adoption of Electric Vehicles in South Africa}

Respondents were presented with an opportunity to state their willingness to purchase electric vehicles in the future given certain technological advances and policy changes, and their results are shown in Figure 1.

What are the odds of purchasing electric vehicles under the following conditions

If government can allow electric vehicles to drive in dedicated bus lanes in major congested roads

If there is a government financial incentive in the form of annual car license renewal and toll gates exemptions

If there is a government financial incentive in the form of tax rebate of a fixed amount

If the vehicle variety in the South African market is increased

If their prices would be comparable with normal cars with the same functions

If there will be a charging station at your workplace

If there will be charging stations at major filling stations around the country

If the driving range can be increased tremendously
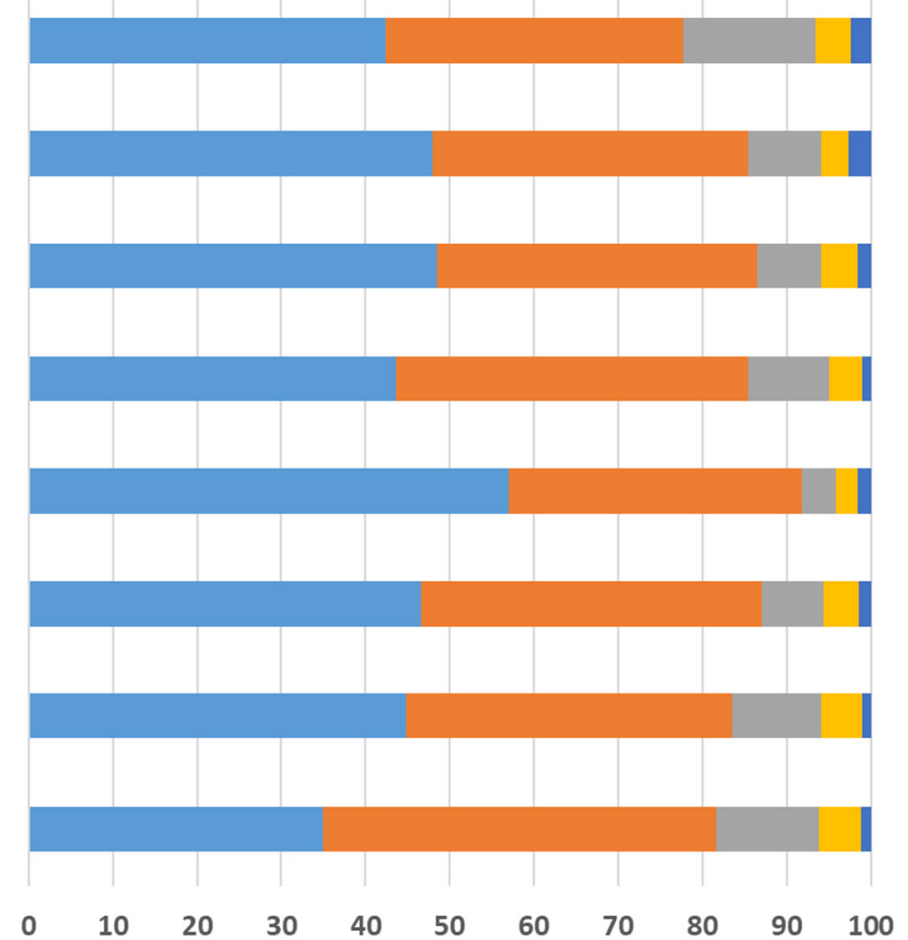

very likely $\quad$ likely neither likely nor unlikely unlikely $\square$ very unlikely

Figure 1. Results of the questionnaire, showing the likelihood of participants to purchase an electric vehicle based on future technological and policy changes in percentages.

Since the driving range of EVs is one of the major thorns in their adoption all over the world [30], respondents are willing (over $80 \%$ ) to make future purchases of EVs if this problem is solved (Figure 1). The chi-square results showed a significant difference in responses by gender (at $5 \%)$, with a considerable percentage of females not eager $(7 \%$ female vs. 3\% male) to purchase EVs even if the driving range is increased (Table 1). In order to fulfil this promise, there has to be major breakthroughs in the development of rechargeable batteries [31]. There are signs of success in this area, as some of the new cars on the market in Europe and North America are proclaimed to have a driving range exceeding $500 \mathrm{~km}$ [31]. Based on this information, consumers will have less range anxiety in the future and the number of electric vehicles on South African roads will definitely increase. 
Table 1. Chi-square test between demographic factors and factors that tend to improve electric vehicle market penetration.

\begin{tabular}{cccccccccc}
\hline Factors & $\mathbf{a}^{+}$ & $\mathbf{b}^{+}$ & $\mathbf{c}^{+}$ & $\mathbf{d}^{+}$ & $\mathbf{e}^{+}$ & $\mathbf{f}^{+}$ & $\mathbf{g}^{+}$ & $\mathbf{h}^{+}$ \\
\hline Age & 0.517 & 0.955 & 0.526 & 0.962 & 0.538 & 0.255 & 0.504 & 0.503 \\
Gender & $0.000^{* *}$ & $0.002^{* *}$ & $0.017^{* *}$ & 0.367 & 0.141 & 0.262 & 0.795 & 1.000 \\
Education & 0.118 & 0.533 & 0.603 & 0.269 & 0.265 & $0.034^{* *}$ & 0.165 & $0.098^{*}$ \\
Region & 0.252 & 0.939 & 0.911 & 0.276 & $0.089^{*}$ & $0.037^{* *}$ & 0.430 & $0.049^{* *}$ \\
Settlement type & $0.013^{* *}$ & 0.791 & 0.441 & $0.019 * *$ & 0.586 & 0.357 & 0.163 & 0.067 \\
Dwelling type & 0.261 & 0.241 & 0.562 & 0.194 & 0.254 & 0.255 & 0.500 & 0.361 \\
Type of car driven & 0.946 & 0.722 & 0.450 & 0.846 & 0.681 & $0.024^{* *}$ & $0.027^{* *}$ & $0.095^{*}$ \\
Daily commuting distance & 0.717 & $0.076^{*}$ & 0.459 & 0.492 & $0.006^{* *}$ & 0.389 & 0.673 & 0.797 \\
Awareness of climate change & 0.205 & $0.018^{* *}$ & $0.037^{* *}$ & 0.728 & $0.040^{* *}$ & 0.209 & $0.068^{*}$ & 0.737 \\
\hline
\end{tabular}

${ }^{+}: \mathrm{a}=$ driving range can be increased tremendously; $\mathrm{b}=$ electric vehicle charging stations are installed at major fuel stations across the country; $\mathrm{c}=$ electric vehicle charging stations are installed at workplaces; $\mathrm{d}=$ electric vehicle price is reduced and is comparable with internal combustion engine vehicles; $\mathrm{e}=$ increased variety of electric vehicles; $\mathrm{f}=$ availability of government tax rebates on electric vehicle purchases; $\mathrm{g}$ = exceptions for annual car licenses renewals and toll gates; $\mathrm{h}$ = government allows electric vehicles to drive on bus lanes on congested roads and during busy times. ${ }^{* *}$ : (significant at $\left.5 \%\right) .{ }^{*}$ : (significant at $\left.10 \%\right)$.

The poor network of charging stations is currently a deterrent measure that prevents consumers from purchasing EVs [2,32]. The charging points that are present in South Africa are not on the major roads, and this can cause a huge inconvenience to motorists. Even though the majority of the respondents in Gauteng indicate that their adoption of electric vehicles can be enhanced if charging stations are present in major filling stations across the country (Figure 1), there is a significant difference in the responses by gender and awareness to climate change at the $5 \%$ significance level (Table 1). A study by Lieven also showed that respondents around the world are dissatisfied by the absence of charging stations on freeways. The presence of this infrastructure at these strategic points would not change the driving patterns of motorists, thus enhancing positive experience on this emerging technology. Thus, there is a need for government to be more involved in the expansion of the charging stations network in South Africa; currently, this expansion has mostly been spearheaded by the private sector, with minimal involvement of the government.

One of the major obstacles that was presented is the lack of convenient charging spots in some countries, including South Africa. It is suggested that placing charging stations at workplaces will resolve this problem. The respondents attest to this notion, with $87 \%$ stating that they are likely to buy an EV if there is a policy that encourages employers to install charging stations in their parking lots (Figure 1). However, there is also a significant difference in the responses by gender (Table 1). This idea should be supported by government subsidies for the employers to compensate their electricity usage during charging. An increase in charging spots will also help curb the pre-conceived range anxiety.

It has been documented all over the world that purchase price is the main constraint for purchasing EVs [2,33]. Currently, EVs are more than twice as expensive as ICE vehicles in their class and the drive to be more environmentally friendly can be suppressed by this constraint [34]. Over $90 \%$ of the respondents in the Gauteng Province show their willingness to purchase an EV if and only if their prices become comparable to the traditional cars (Figure 1). However, there is a significant difference in responses according to settlement type at a $95 \%$ confidence level (Table 1). In order to bridge this price gap, a number of countries in the developed world and emerging economies have introduced lucrative incentives to new EV purchases [35]. Incentives of reducing purchase price are found to be the most effective in the adoption of EVs and increase in market share [11]. This has been a successful intervention by governments in Europe and China, with other countries being encouraged to follow [20,36]. Norway managed to achieve a market share of $18 \%$ in 2015 due to the incentives, which have been consistently enhanced since 1990 [11]. It has to be noted that EV adoption needs greater persistence from all stakeholders.

In most areas, electric vehicles are compact cars, and the variety is very low compared with that of ICE cars. The difficulty to obtain an electric SUV or bakkie in South Africa can be challenging to some of the consumers whose travel routes include untarred roads. Even though the respondents show that they are willing to buy an electric vehicle if there can be 
a variety of classes (Figure 1), there are significant differences in responses according to the daily community distances and awareness of climate change at a $5 \%$ significance level (Table 1). In other areas where the technology has been piloted for a number of years, there have been a lot of new classes that have been introduced to the market to stimulate the adoption [37,38]. In recent times, there were also new entrants to the South African market that has increased the variety of EVs.

As stated earlier, governments have a major role to play in ensuring that electric vehicles are adopted by the majority in order to achieve their mitigation obligations. One of the main initiatives has been the introduction of tax rebates of a fixed amount $[33,36]$. This makes the EVs more affordable and is an indication that governments are also committed to the cause of combating climate change. Around $86 \%$ of the people show strong support to the idea (Figure 1), but there are significant differences in responses according to education, region and type of car driven (Table 1). In Norway, EVs are exempted from registration tax, which can exceed 3000 Euros depending on the emission level, engine size and weight of the vehicle [11]. It can be noted that rebates alone will not change the purchasing behaviour of consumers. Other initiatives, such as basic educational programs on TV and print and online campaigns, can ensure that people are well informed and are in a position to make the right choices $[39,40]$.

The introduction of exemptions on annual car registration renewal has the potential to induce more people to consider purchasing electric vehicles [11]. This can be coupled with toll gate exemptions and free charging in malls [36]. The results show that over $85 \%$ of the people believe that this incentive can entice them to purchasing EVs, even though there is a significant difference in responses by type of car driven (Table 1). A number of countries, such as Norway, have adopted this policy, and people have responded positively to this initiative [41]. Other incentives in some countries include VAT exemptions, which were introduced to enable the EVs to compete with ICE vehicles on the market [11].

Another intervention will be that of allowing EVs to use dedicated bus lanes in major congested roads [11,33]. This initiative showed the lowest appreciation, with only $77 \%$ of the people stating that it might influence them in purchasing an EV (Figure 1) with significant differences according to region (5\%), education (10\%) and type of car driven $(10 \%)$. This can be a major incentive to motorists residing in Gauteng, especially in peak hours taking into consideration the density of charging stations. This initiative has worked extremely well in other parts of the world [36].

\subsection{Role of the South African Policies towards EV Adoption}

The importance of advancing the electrification of the transport sector has been highlighted in many studies, as the greenhouse gas emissions from the transport sector continue to rise [42-44]. Research findings by Pautasso et al. [45] and other scientists also showed that adjusting government policies to enable shifting from ICE to electric vehicles has the potential to bear the following benefits over and above environmental considerations: (a) better health conditions for the citizens due to reduced air pollution [46], (b) potential monetary savings in the public health sector due to reduced respiratory diseases caused by air pollution [45], (c) reduction of noise pollution, which will benefit society in a number of ways $[47,48]$ and (d) improved energy security caused by reduced reliance on exported fossil fuels and high volatility attached to crude oil prices [15,49].

There is an extremely low penetration of electric vehicles on the South African market. The main barriers identified include: low percentage of climate-conscious consumers [15], high import duties for vehicles [15], current products not covering an array of consumer needs in South Africa [15] and the high costs of electric vehicles [16]. Most of these barriers can be addressed by drafting and implementation of sound government policies. The lack of policy to address these issues demonstrates to a certain extent a country's lack of commitment in meeting its reduction targets. Consumer educational programmes can be increased to sensitize the communities of the importance of EVs in the fight against climate change. Other factors can be addressed by further developments in the electric 
vehicle technology and increased drive for current world leaders in vehicle manufacturing to expand their EV production.

Government policies are found to play a critical role towards the adoption of electric vehicles around the world [21,36,41]. In the case of South Africa, the climate change response white paper highlighted the importance of EVs in the fight against climate change by instructing the Department of Transport to initiate a programme that promotes the use of hybrid and electric vehicles [50]. The Gauteng government has drafted a policy on promoting green transport in 2014, but the emphasis was on the decarbonisation of public transport [51]. The green transport strategy is the first main legislature that specifically set the scene for the reduction of greenhouse gas emissions in the transport sector through the promotion of low carbon mobility solutions [4]. The strategy aims at creating and enabling an environment that incentivises the adoption of low or zero tailpipe emission vehicles [4].

The Department of Transport seeks to engage all government institutions in the future to adopt low carbon technologies under the vehicle energy efficiency programme [4]. There is also a drive to develop a policy for new energy vehicles, as outlined in the Auto Green Paper under discussion and public consultations in 2021 [52]. To stimulate the private sector, the Department of Transport together with the Department of Science and Innovation will pave the way for manufacturing incentives for electric vehicles in an effort to increase the local content in future mobility solutions in the country [4]. The government is also proposing to introduce a policy that will scrap all ICE vehicles with a mileage of 400,000 kilometres or more on the roads. This will aid in reducing high-emitting vehicles on the roads and increasing electric vehicle purchases through other complementary strategies envisaged. The other initiative is on the possible introduction of incentives to lower the prices of EVs in an effort to improve competition with ICE vehicles on the market [4]. This strategy has been highly successful in Europe and China, resulting in an enhanced adoption of EVs in those regions [20,33]. In an effort to educate the public, the Department of Transport seeks to initiate green transport awareness campaigns around the country [4].

The introduction of a carbon tax on new vehicle purchases which produce tailpipe emissions is another initiative that tends to promote electric vehicles [53]. Starting from September 2010, all new ICE vehicles that have emission rates exceeding $120 \mathrm{~g} / \mathrm{km}$ have been subjected to this carbon tax [54]. An amount of 75 Rands for every $\mathrm{g} / \mathrm{km}$ is charged above the threshold [55]. The upper-limit for double cabs has been set at $175 \mathrm{~g} / \mathrm{km}$, with additional $\mathrm{g} / \mathrm{km}$ being charged at 100 Rands [55]. Vehicles that lack credible emissions data are charged based on their engine size. These efforts are meant to accelerate the introduction of cleaner technologies on South African roads. In the future, the current environmental levy will be reviewed to include other vehicle categories, such as commercial vehicles, which are currently excluded in a drive to improve environmental performance of the country's vehicles [4]. Over and above the ones-off vehicle carbon tax, the government of South Africa is reviewing the introduction of an annual tax on cars based on their emission levels [4]. These future initiatives have the potential to change the electric vehicle environment in South Africa.

As shown in a number of countries where electric vehicles have been successful, government intervention has been key towards providing both financial and non-financial incentives. Early adopters of EVs were mostly lured by the fiscal incentives, but the latest research shows that incentives are no longer the main driver for the market share increase in developed countries, with factors such as an increase in fuel prices and increased public charging stations being the main factors [56]. It is, thus, critical for the South African automotive industry and government to put in place incentives that will increase the diffusion of EVs on the market and break some of the barriers present.

\section{Conclusions}

Even though the participants of the questionnaire on barriers to adoption of electric vehicles in Gauteng showed positive sentiments, they still indicate that a number of factors need to be changed in order for them to buy an electric vehicle in the future. Policy 
incentives are considered as one of the most effective measures that can ensure that electric vehicle sales increase. The government has a role to play in ensuring that there are enough incentives for companies that are willing to invest in manufacturing EVs in South Africa. The government should also carefully consider the issue of consumer subsidies for the purchase of the vehicles, as this was found to be the main constraint in this study and other studies across the world. Dedicating resources to research and development in the country will ensure local content that can improve the acceptability of the technology by the consumers. Other considerations for the government are the issuing of exemptions on toll gates and other transport-related levies. In order to improve on range anxiety, the government should consider the issue of expanding the quick charging stations at strategic areas in partnership with the private sector. Currently, in South Africa, vehicle manufacturers are the ones heavily ensuring that charging station density is increased across the country. In countries which have government support for the technology, the market share of EVs has increased tremendously. The government of South Africa has adopted the Green Transport strategy, which will enable the widespread adoption of electric vehicles through a number of proposed initiatives. The implementation of the strategies suggested in this strategy will enhance the chances of South Africa meeting their mitigation obligations. Since this study has some limitations regarding sample size and coverage, further comprehensive studies targeting all segments of the population of South Africa are needed in the future.

Funding: This research was funded by the Agricultural Research Council (South Africa).

Institutional Review Board Statement: Not applicable.

Informed Consent Statement: Informed consent was obtained from all subjects involved in the study.

Data Availability Statement: Not applicable.

Acknowledgments: Authors thank all the colleagues from the Agricultural Research Council who assisted in the collection of data. Thomas Fyfield is thanked for editing this manuscript.

Conflicts of Interest: The authors declare no conflict of interest.

\section{References}

1. Samara, S. Electric Cars: Perception and Knowledge of the New Generation Towards Electric Cars. Master's Thesis, School of Economics, Erasmus University Rotterdam, Rotterdam, The Netherlands, 2016.

2. Gärling, A.; Thøgersen, J. Marketing of electric vehicles. Bus. Strateg. Environ. 2001, 10, 53-65. [CrossRef]

3. Zhang, R.; Fujimori, S. The role of transport electrification in global climate change mitigation scenarios. Environ. Res. Lett. 2020, 15, 034019. [CrossRef]

4. Department of Transport. Draft Green Transport Strategy (2017-2050) (Government Gazette No. 41064, 25 August 2017); Department of Transport: Pretoria, South Africa, 2017.

5. Ajanovic, A.; Haas, R. Dissemination of electric vehicles in urban areas: Major factors for success. Energy 2016, 115, 1451-1458. [CrossRef]

6. Stats SA. Sustainable Development Goals: Country Report 2019. Statistics South Africa. 2019. Available online: http://www. statssa.gov.za/MDG/SDGs_Country_Report_2019_South_Africa.pdf (accessed on 25 September 2021).

7. Daina, N.; Sivakumar, A.; Polak, J.W. Modelling electric vehicles use: A survey on the methods. Renew. Sustain. Energy Rev. 2017, 68, 447-460. [CrossRef]

8. Woo, J.R.; Choi, H.; Ahn, J. Well-to-wheel analysis of greenhouse gas emissions for electric vehicles based on electricity generation mix: A global perspective. Transp. Res. Part D Transp. Environ. 2017, 51, 340-350. [CrossRef]

9. Thell, L.; Ly, S.; Sundin, H. Electric Cars, the Climate Impact of Electric Cars, Focusing on Carbon Dioxide Equivalent Emissions. 2012. Available online: https:/ / www.diva-portal.org/smash/get/diva2:529571/FULLTEXT01.pdf (accessed on 18 December 2018).

10. Jabeen, F.; Olaru, D.; Smith, B. Acceptability of Electric Vehicles: Findings from a Driver Survey. 2012. Available online: https:/ / therevproject.com/publications/uwa/C2012-ATRF-Acceptability\%20Of\%20Electric\%20Vehicles:\%20Findings\% 20From\%20A\%20Driver\%20Survey-Jabeen\%20Braunl\%20Et\%20Al-ref.pdf (accessed on 26 December 2018).

11. Figenbaum, E. Perspectives on Norway's supercharged electric vehicle policy. Environ. Innov. Soc. Transit. 2017, 25, 14-34. [CrossRef]

12. Wheels24.co.za Electric Vehicles in SA: Uptake of EVs Slow but Steady. 2018. Available online: https://www.wheels24.co.za/ News/Gear_and_Tech/electric-vehicles-in-sa-uptake-of-evs-slow-but-steady-20180116 (accessed on 16 November 2018). 
13. Venter, I. Electrified Vehicle Sales in South Africa Remain Dismal, Says uYilo. Engineering News. 2021. Available online: https: //www.engineeringnews.co.za/article/electrified-vehicle-sales-in-south-africa-remain-dismal-says-uyilo-2021-04-12 (accessed on 4 September 2021).

14. Daniel, L. Just 92 Electric Vehicles Were Sold in SA Last Year-Here's How Govt Plans to Boost the Market. Business Insider SA. 2021. Available online: https:/ / www.businessinsider.co.za/governments-plan-to-sell-more-electric-vehicles-in-south-africa2021-5 (accessed on 4 September 2021).

15. Raw, B.; Jack, R. Electric Vehicles 2020: Market Intelligence Report. 2020. Available online: https:/ /www.greencape.co.za/assets/ Uploads/ELECTRIC_VEHICLES_MARKET_INTELLIGENCE_REPORT_25_3_20_WEB.pdf (accessed on 12 September 2021).

16. Moeletsi, M.E. Socio-Economic Barriers to Adoption of Electric Vehicles in South Africa: Case Study of the Gauteng Province. World Electr. Veh. J. 2021, 12, 167. [CrossRef]

17. Kwame, B.M. Unpacking the Technical and Perception Barriers To Electric Vehicle Uptake in South Africa. Master's Thesis, Stellenbosch University, Stellenbosch, South Africa, 2019.

18. Lai, I.K.W.; Liu, Y.; Sun, X.; Zhang, H.; Xu, W. Factors Influencing the Behavioural Intention towards Full Electric Vehicles: An Empirical Study in Macau. Sustainability 2015, 7, 12564-12585. [CrossRef]

19. Butler, N. Why the Future of Electric Cars Lies in China. Financial Times. 2018. Available online: https://www.ft.com/content/ 1c31817e-b5a4-11e8-b3ef-799c8613f4a1 (accessed on 31 December 2018).

20. Zhang, X.; Xie, J.; Rao, R.; Liang, Y. Policy incentives for the adoption of electric vehicles across countries. Sustainability 2014, 6, 8056-8078. [CrossRef]

21. Wang, S.; Wang, J.; Li, J.; Wang, J.; Liang, L. Policy implications for promoting the adoption of electric vehicles: Do consumer's knowledge, perceived risk and financial incentive policy matter? Transp. Res. Part A Policy Pract. 2018, 117, 58-69. [CrossRef]

22. Globaldata. Energy Electric Vehicle Market Gaining Momentum in India. 2018. Available online: https://www.power-technology. com/comment/electric-vehicle-market-gaining-momentum-india/ (accessed on 2 January 2019).

23. Dane, A. The Potential of Electric Vehicles to Contribute to South Africa's Greenhouse Gas Emissions Targets and Other Developmental Objectives: How Appropriate Is the Investment in Electric Vehicles as a NAMA? Cape Town. 2013. Available online: https:/ / media.africaportal.org/documents/13-Dane-Electric_vehicles.pdf (accessed on 28 December 2018).

24. Department of Environmental Affairs. South Africa's Intended Nationally Determined Contribution (INDC). 2015. Available online: https://www4.unfccc.int/sites/ndcstaging/PublishedDocuments/South\%20Africa\%20First/South\%20Africa.pdf (accessed on 12 December 2018).

25. Moeletsi, M.E. Electric Cars: Their Carbon Implications and Adoption in South Africa. Master's Thesis, Business School, Nelson Mandela University, Port Elizabeth, South Africa, 2019.

26. Krupa, J.S.; Rizzo, D.M.; Eppstein, M.J.; Lanute, D.B.; Gaalema, D.E.; Lakkaraju, K.; Warrender, C.E. Analysis of a Consumer Survey on Plug-In Hybrid Electric Vehicles. Transp. Res. Part A Policy Pract. 2014, 64, 14-31. [CrossRef]

27. Jabeen, F. The Adoption of Electric Vehicles: Behavioural and Technological Factors. Ph.D. Thesis, Businnes School, The University of Western Australia, Perth, Australia, 2016.

28. StatisticsHowTo. Cronbach's Alpha: Simple Definition, Use and Interpretation. 2014. Available online: https://www. statisticshowto.com/cronbachs-alpha-spss / (accessed on 12 November 2018).

29. Tavakol, M.; Dennick, R. Making sense of Cronbach's alpha. Int. J. Med. Educ. 2011, 2, 53-55. [CrossRef]

30. Tsang, F.; Pedersen, J.S.; Wooding, S.; Potoglou, D. Bringing the Electric Vehicle to the Mass Market a Review of Barriers, Facilitators and Policy Interventions; Working Papers; RAND Corporation: Santa Monica, CA, USA, 2012; pp. 1-77.

31. Bessenbach, N.; Wallrap, S. Why Do Consumers Resist Buying Electric Vehicles? 2013. Available online: http:/ / studenttheses.cbs. dk/bitstream/handle/10417/4329/nadine_bessenbach_og_sebastian_wallrapp.pdf (accessed on 15 December 2018).

32. Bonges, H.A.; Lusk, A.C. Addressing electric vehicle (EV) sales and range anxiety through parking layout, policy and regulation. Transp. Res. Part A Policy Pract. 2016, 83, 63-73. [CrossRef]

33. Langbroek, J.H.M.; Franklin, J.P.; Susilo, Y.O. The effect of policy incentives on electric vehicle adoption. Energy Policy 2016, 94 , 94-103. [CrossRef]

34. Ginsberg, J.M.; Bloom, P.N. Choosing the Right Green Marketing Strategy. MIT Sloan Manag. Rev. 2004, 46, 79-84.

35. Rezvani, Z.; Jansson, J.; Bodin, J. Advances in consumer electric vehicle adoption research: A review and research agenda. Transp. Res. Part D Transp. Environ. 2015, 34, 122-136. [CrossRef]

36. Lieven, T. Policy measures to promote electric mobility-A global perspective. Transp. Res. Part A Policy Pract. 2015, 82, 78-93. [CrossRef]

37. PluginIndia. Electric Vehicles in India. 2018. Available online: http://www.pluginindia.com/vehicles.html (accessed on 2 January 2019).

38. ITDP. China Tackles Climate Change with Electric Buses. 2018. Available online: https://www.itdp.org/2018/09/11/electricbuses-china/ (accessed on 2 January 2019).

39. Jin, L.; Slowik, P. Literature Review of Electric Vehicle Consumer Awareness and Outreach Activities. 2017. Available online: https: / theicct.org/publications/literature-review-electric-vehicle-consumer-awareness-and-outreach (accessed on 30 December 2018).

40. Argue, C.; Hou, E. Emotive-Promoting the Electric Vehicle Experience. World Electr. Veh. J. 2016, 8, 685-690. [CrossRef]

41. Contestabile, M.; Alajaji, M. Will Current Electric Vehicle Policy Lead to Cost-Effective Electrification of Passenger Car Transport? Green Energy Technol. 2018, 110, 75-99. [CrossRef] 
42. Umar, M.; Ji, X.; Kirikkaleli, D.; Alola, A.A. The imperativeness of environmental quality in the United States transportation sector amidst biomass-fossil energy consumption and growth. J. Clean. Prod. 2021, 285, 124863. [CrossRef]

43. Song, Y.; Zhang, M.; Shan, C. Research on the decoupling trend and mitigation potential of CO2 emissions from China's transport sector. Energy 2019, 183, 837-843. [CrossRef]

44. Raza, M.Y.; Lin, B. Decoupling and mitigation potential analysis of $\mathrm{CO}_{2}$ emissions from Pakistan's transport sector. Sci. Total Environ. 2020, 730, 139000. [CrossRef] [PubMed]

45. Pautasso, E.; Osella, M.; Caroleo, B. Addressing the Sustainability Issue in Smart Cities: A Comprehensive Model for Evaluating the Impacts of Electric Vehicle Diffusion. Systems 2019, 7, 29. [CrossRef]

46. Wu, J.; Liao, H.; Wang, J.W.; Chen, T. The role of environmental concern in the public acceptance of autonomous electric vehicles: A survey from China. Transp. Res. Part F Traffic Psychol. Behav. 2019, 60, 37-46. [CrossRef]

47. Pardo-Ferreira, M.d.C.; Rubio-Romero, J.C.; Galindo-Reyes, F.C.; Lopez-Arquillos, A. Work-related road safety: The impact of the low noise levels produced by electric vehicles according to experienced drivers. Saf. Sci. 2020, 121, 580-588. [CrossRef]

48. Kumar, M.S.; Revankar, S.T. Development scheme and key technology of an electric vehicle: An overview. Renew. Sustain. Energy Rev. 2017, 70, 1266-1285. [CrossRef]

49. Li, Y.; Chang, Y. Road transport electrification and energy security in the Association of Southeast Asian Nations: Quantitative analysis and policy implications. Energy Policy 2019, 129, 805-815. [CrossRef]

50. Department of Environmental Affairs. National Climate Change Response White Paper; Department of Environmental Affairs: Pretoria, South Africa, 2011; pp. 1-86.

51. Department of Roads and Transport. Promoting Sustainable (Green) Transport in Gauten; Department of Roads and Transport: Johannesburg, South Africa, 2014; p. 24.

52. Department of Trade Industry \& Competition. Auto Green Paper on the Advancement of New Energy Vehicles in South Africa (Public Consultation Version); Department of Trade Industry \& Competition: Pretoria, South Africa, 2021; pp. 1-15.

53. SA Treasury. Carbon Tax Bill; National Treasury: Pretoria, South Africa, 2018; pp. 1-32.

54. Group1Nissan. South African Vehicles and Carbon Emissions. 2019. Available online: https://www.group1nissan.co.za/carbonemissions / (accessed on 2 December 2019).

55. National Treasury. Press Release Regarding CO2 Vehicle Emissions Tax. 2010. Available online: http://www.treasury.gov.za/ comm_media/press/2010/2010082601.pdf (accessed on 13 December 2019).

56. Wang, N.; Tang, L.; Pan, H. A global comparison and assessment of incentive policy on electric vehicle promotion. Sustain. Cities Soc. 2019, 44, 597-603. [CrossRef] 